\title{
Comparison of Real-Time PCR and Cultural method for Detection of Bacterial load in pasteurized milk
}

\author{
Ayda Farhoudi', ${ }^{1}$ Peyman Ghajarbeygi ${ }^{2}$, Razi allah Jafari jozani ${ }^{3}$, Razzagh \\ Mahmoudi* $^{4}$ and Karim Mardani ${ }^{5}$
}

1. School of Public Health, Qazvin University of Medical sciences, Qazvin, Iran;

2. Health Products Safety Research Center, Qazvin University of Medical sciences, Qazvin, Iran;

3. Department of Clinical sciences, Faculty of Veterinary Medicine, University of Tabriz, Iran;

4. Medical Microbiology Research Center, Qazvin University of Medical sciences, Qazvin, Iran;

5. Department of Food Hygiene and Quality Control, Faculty of Veterinary Medicine, Urmia University, Iran

*Corresponding Author: Razzagh Mahmoudi, Qazvin University of Medical Sciences, Qazvin, Iran, E-mail: r.mahmodi@yahoo.com

\begin{abstract}
In this study, we used a TaqMan ${ }^{\circledR}$ probes through the real-time PCR technique as a rapid and sensitive way to detect bacterial load of pasteurized milk. The reaction was optimized for enumeration of bacteria in pasteurized milk samples. In parallel the same milk samples were assessed by conventional cultural-based method. The correlation between methods was evaluated by Bland Altman analysis. The minimum and maximum value for conventional culture-based method were 0 and $10000 \mathrm{cfu} / \mathrm{ml}$ while qPCR gave us 55 and 7071 (Bacteria/ml of pasteurized milk), respectively. Results indicated that, Taq Man Real Time PCR provides a useful tool for rapid and accurate quantification of bacterial load.
\end{abstract}

Keywords: pasteurized milk, bacterial load, Real Time PCR

\section{Practical applications:}

This is the author manuscript accepted for publication and has undergone full peer review but has not been through the copyediting, typesetting, pagination and proofreading process, which may lead to differences between this version and the Version of Record. Please cite this article as doi: $10.1111 /$ jfs.12624

This article is protected by copyright. All rights reserved. 
Dairy industries are required to determine total bacterial load in farmer's raw milk before collection based on legal standard methods for microbial detection. Moreover, the result of total bacterial counting is the major pricing criterion of raw milk. Despite the storage of raw milk from large farms in separate tanks, raw milk from small and medium size farms are mixed in other tanks resulting in total bacterial load alteration. Traditional cultural- based methods are common to determine total bacterial load in raw milk. But these techniques are laborious and time consuming. Recent molecular-based methods are easily applicable to ensure that perishable raw milk could be monitored precisely under national rules and legislation in shortest possible time. This report provides the details of a TaqMan Real-Time PCR (qPCR) that can be used in factory sites for accurate monitoring of raw milk bacterial load before transferring the raw milk into pasteurization line.

\section{Introduction}

Milk is known as an excellent source of nutrient. It contains many valuable compounds such as vitamins and minerals and essential amino acids which have important role in human health (Theresa et al., 2003). Therefore, it's strictly recommended to every people whether young or old. As milk is a perishable product and might contain pathogens, it has the potential to cause food borne diseases (Guh et al., 2010). Milk is a suitable medium to support the growth of some pathogenic bacteria such as Escherichia Coli which is responsible for gastrointestinal infections in young children and elderly people (Blachaly et al., 2004). So the proper quality control of milk is important to make sure of its safety. Each country enforces legal standard methods for microbial detection in milk and in its products (Naun et al., 2007). Conventional cultural- based methods are common to detect bacterial load in milk. But these methods are laborious and time consuming, in most cases take up to almost 72 hours to cultivate (Gammon et al., 2007). Some dead and stressed cells and microorganism can't be detected by the conventional method and some special incubation condition such as temperature and atmosphere may be needed for this method to be able to support the growth of those fastidious agents (Juste et al.2008). Food safety management system obligates that detection should get result in shortest possible time, especially for perishable food products like pasteurized milk. New molecular-based methods which have been developed recently are easily applicable to ensure that food products could be monitored precisely under national rules and legislation in quickest possible time. Quantitative Real-Time PCR (qPCR) can be used in managing of food safety and quality control. It is the strongest method for precisely detect and enumeration of bacterial pathogens (Levin, 2004). It is fast and accurate (Amagliani et al., 2010) and also there are lots of handy methods which have been widely developed in food microbiology to assist molecular detection of pathogenic agents (Omiccio et al., 2009). 
The aim of this study was to establish and optimize a Taq Man Real-Time PCR assay it for rapid detection and enumeration of bacterial load in pasteurized milk samples. For this purpose, using a previously reported primer set and a Taq Man prob first we established a Real - Time PCR assay. Then, the results of bacterial load based on Real - Time PCR were compared with conventional culture-based method.

\section{Material and Methods}

\subsection{Sample Preparation}

100 pasteurized milk samples were purchased early morning, from different supermarkets in Tabriz, Iran. All samples transmitted immediately to the laboratory of Department of Food Hygiene and Aquatics, University of Tabriz, Iran for further bacterial culture and molecular analysis.

\subsection{Cultural method}

All samples were cultured based on the national standard of Iran for microbial of milk and milky products (ISIRI 2406).

Following the Standard procedures, the samples were cultured on Plate Count Agar medium and incubated in $37^{\circ} \mathrm{C}$, after 48 hours colonies were counted based on colony counting method obtained results were recorded.

\subsection{DNA Isolation}

First, $50 \mathrm{ml}$ of each milk samples were pelleted by centrifugation at $1200 \times \mathrm{g}$ for $45 \mathrm{~min}$. Pellets from milk samples were re suspended in $50 \mathrm{ml}$ TAE buffer $(10 \mathrm{mMol}$ Tris- $\mathrm{HCl}, 1$ mMol EDTA, and $\mathrm{pH}$ 8) and re centrifuged as above. Then, DNA was isolated from the pellets using a DNA extraction kit (AccuPrep Genomic DNA Extraction Kit, BIONEER, South Korea). To estimate DNA concentration, its optical absorption was read at wavelength of $260 \mathrm{~nm}$ and $280 \mathrm{~nm}$ using photometer (Biophotometer. Eppendorf, Germany).

\section{4. $\quad$ Primers and prob}

A set of previously reported universal primers pair and a labeled prob with FAM and TAMRA for 16S rDNA based on E.coli O157:H7 (accession number AF034253) that target a 166 bp fragment of DNA was used. (Stephan J. Ott, 2004). The forward and Reverse primers and also probe sequence are introduced in Table 1.

\subsection{Real-Time PCR and Standard PCR}

For real-time PCR, master plus (Jena Bioscience, Jena, Germany) was used in a Rotogen Real Time PCR System (Rotogen 6000, QIAGEN, Germany). Twenty microliters of reaction mix containing $10 \mu \mathrm{L}$ of master plus I, $1 \mu \mathrm{L}$ of each primer and prob (35 ng), 2.5 $\mu \mathrm{L}$ of the template $(10 \mathrm{ng})$ and $4.5 \mathrm{mg}$ of double distilled water (Sinaga, Tehran, Iran). For non-template controls (NTC), the template was replaced by double distilled water (Sinagen, 
Tehran, Iran). The efficiency of each reaction was calculated according to this formula: $\mathrm{E}=$ (10(1/slope) $) 1)$. All the reactions were performed in triplicate.

Thermal conditions Real-Time PCR were $94{ }^{\circ} \mathrm{C}$ for 5 minutes plus 40 cycles of $94{ }^{\circ} \mathrm{C}$ for 25 seconds and $60^{\circ} \mathrm{C}$ for 25 seconds.

For visualizing the amplification products a standard PCR was conducted. The thermal steps for amplification of DNA were: $94{ }^{\circ} \mathrm{C}$ for 5 min then, 40 cycles of $95^{\circ} \mathrm{C}$ for 25 seconds $61{ }^{\circ} \mathrm{C}$ for 45 seconds, $72{ }^{\circ} \mathrm{C}$ for 1 minutes and finally $72{ }^{\circ} \mathrm{C}$ for 10 minutes. After $1.5 \%$ agarose gel electrophoresis and RedSafeTM staining, amplification products were visualized under U.V.

\subsection{Statistical Analysis}

Using Bland-Altman Plot, we compared the compatibility of obtained data from conventional cultural-based method with the results of Real-Time assay.

\section{Results}

\subsection{Cultural Results}

A total of 100 pasteurized milk samples were investigated. According to the result, \%33 of all sample had contamination more than the acceptable levels of national standard of Iran for microbiology of milk and milk products - specifications (ISIRI 2406). Table 2 shows the result of bacterial load of samples. The maximum and minimum results of cultural test were 10000 and 0 (cfu/ml) respectively.

\subsection{DNA Extraction}

For all pasteurized milk sample, genomic DNA appeared with high intensity. The DNA concentrations for all samples were between 50 and $111 / 2 \mu \mathrm{g} / \mathrm{ml}$.

\section{3. $\quad$ PCR and Real-Time PCR}

To evaluate the performance of the primer pair, a conventional PCR reaction was run. As we expected, a specific band of 166 bp was observed (Fig.1). According to quantitative result of Real-Time PCR, the maximum and minimum copy numbers of bacterial rDNA fragments were 7071 and 55, equivalent to 7071 and 55 bacterial cells in ml of pasteurized milk. With the using plasmid DNA form E.coli (data was not shown) with concentration of 50, 600, 5000 (copies/ml) a standard curve was obtained (Fig. 2).

Based on Standard Curve, Slope and y-intercept were -2.98369 and 33.09691 respectively. The efficiency of Real time PCR assay was $>99 \%$ (Fig. 2). The standard curve formula to calculate concentration of microorganisms was Conc $=10^{\wedge}\left(-0.335^{*} \mathrm{CT}+11.093\right)$. 


\section{Discussion}

In this work, we applied a Taq-Man Real-Time PCR based assay for the rapid determination of bacterial load in PM samples.

The method consisted of preliminary DNA extraction of the samples, followed by analyzing extracted DNA. They were assessed in terms of quality and quantity. We set up Taq-Man Real-Time PCR and considered results as (Bacteria/ml) to be similar with the results of culture.

According to the results of molecular and conventional tests which are presented in Table1, in general there are some variations in quantitating of bacterial load by both methods. The result of Real-Time PCR and cultural methods was compared for determination of the tests agreement by Bland-Altman Plot (Fig. 2). According to the Bland-Altman Plot, the difference of results were high (-5105 and 3881), so there were no agreement between the two methods. The same results were seen in a previous report by Hein (Hein et al., 2005). They evaluated unpasteurized milk for presence of S. aureus according to the standard bacterial culture and SYBER Green Real-Time PCR methods. In aforementioned study a poor agreement between the quantitative output of the Real-Time PCR and the bacterial culture method was observed (Hein et al., 2005). Yen Thi reported that development of sensitive and specific TaqMan Real-Time PCR assay allowing a rapid and reliable identification of A.suum larvae in meat and organs meat. (Nguyen et al., 2016).

The difference between Real-Time PCR result and CFU changes during bacterial growth has been reported by Ludwig (Ludwig, 2000). Makino estimated the pathogens number in dairy product by using Real-Time PCR, 10 logs more than number of some pathogens by the bacterial culture methods (Makino et al., 2010). Messerhausser indicated differences between conventional and Real-Time PCR. Real- Time Quantitative detection of Yersinia enterocolitica in pork samples lead to identification of $18 \%$ of samples infected by the pathogen while the same figure based on conventional Cultural method was only $10 \%$. (Messerhausser et al., 2011). The comparison of the data from raw milk for detection of four food - borne pathogens from both methods in Italy showed that the Real-Time PCR (RTPCR) method detected Salmonella, Listeria monocytogenes, Escherichia Coli O157, and Campylobacter jejuni in $0.12,1.29,0.51$, and $1.35 \%$ of the samples, respectively, whereas the bacterial culture method detected these pathogens in $0.04,0.35,0.05$, and $0.14 \%$ of samples, it's revealed that Real-Time PCR was up to 9.40 times more sensitive than the culture based methods (Ferderica et al., 2013). Hein reported higher bacterial count with Real-Time PCR in comparison with bacterial culture method, in which the real-time PCR method yielded 19.3\% more positive samples than the bacterial cultural methods (Hein, et al., 2005). Priha have also reported variation in quantifying Bacillus cereus from different food by Real- Time PCR and conventional methods, the number of Bacillus cereus group bacteria in samples were between 102 -103 and Real Time PCR gave significantly higher results than culturing (Priha et al., 2004). Such discrepancies could be explained by the presence of dead cells or some viable cell but non cultivable forms, which cannot be cultured by bacterial cultural methods. (Nogva, 2003; Makino, 2010; Martinez- Blanch et al., 2009).

The effect of pasteurization on some milk's bacteria causes them to lose ability of proliferation, so they were not enumerated by conventional culture methods. According to standard protocols of Iranian national standard organization, more than 103 bacteria in each 
milliliter of PM is unacceptable, in our study, 33/3\% of PM samples had contamination more than legal level. So, it can be concluded that quality of pasteurization in more than half of PM samples in Azerbaijan Iran are acceptable. Moreover, the overall analyzing period for determination of microbial load by Real-Time PCR was approximately 3 hours, in contrast with conventional culture method for which 48 to 72 hours or even more required, though this methods can be inexpensive. (Hough et al., 2002). In conclusion, the results of this study showed that conventional cultural methods lead to a more divers results in terms of bacterial enumeration while Real - Time PCR showed more coherent and focused results. Real-Time PCR can be used it as a stronger tool for identification and enumeration of bacteria in milk samples and it can be applied as an alternative and improved method instead of conventional cultural methods.

\section{Acknowledgments}

This work was financially supported by Qazvin University of Medical sciences.

\section{References}

Amagliani G, Omiccioli E, Brandi G, Bruce I J, Magnani M. (2010). A multiplex magnetic capture hybridisation and multiplex realtime PCR protocol for pathogen detection in seafood. Food Microbial, 27: 580-585.

Blackall DP, Marques MB. (2004). Hemolytic uremic syndrome revisited: Shiga toxin, factor $\mathrm{H}$, and fibrin generation. American Journal of Clinical

Pathology, 121: 81-88

Federica G, Paolo B, Andrea S, Angelo P, Simonetta A, Norma A, manila B, Stefano B and et al. (2013). Four-Year Monitoring of Foodborne Pathogens in Raw Milk sold. Journal of Food Protection, 76(11): 1902-1907

Gammon K S, Livens S, Pawlowsky K, Rawling S J, Chandra S, Middleton A M. (2007). Development of real-time PCR methods for the rapid detection of low concentrations of Gluconobacter and Gluconacetobacter species in an electrolyte replacement drink. Letters in Applied Microbiology, 44: 262-267.

Guh A, Phan Q, Nelson R, Purviance K, Milardo E, Kinney S, Mshar P, Kasacek W, Cartter M. (2010). Outbreak of Escherichia coli O157 associated with raw milk, Connecticut Clin Infect Dis, 51: 1411-1417. 
Hein I, Jorgensen H J, Loncarevic S, Wagner M. (2005). Quantification of Staphylococcus aureus in unpasteurized bovine and carina milk by real-time PCR. Res Microbial, 156: 554563.

Hough A J, Harbison S A, Savill M G, Melton L D, Fletcher G. (2002). Rapid enumeration of Listeria monocytogenes in artificially contaminated cabbage using real-time polymerase chain reaction J. Food Protection, 65: 1329-1332.

Nogva H K, Drømtorp M S, Nissen H, Rudi K. (2003). Ethidium monoazide for DNA-based differentiation of viable and dead bacteria by 5_-nuclease PCR. BioTech, 34: 804-813.

Juste A, Thomma B P, Lievens B A. (2008). recent advances in molecular techniques to study microbial communities in food associated matrices and processes. Food Microbiology, 25: 745-761.

Levin RE. (2004). The application of real-time PCR to food and Agricultural systems, A review. Food Biotechnology, 18: 97-133.

Makino H, Fujimoto J, Watanabe K. (2010). Development and evaluation of a real-time quantitative PCR assay for detection and enumeration of yeasts of public health interest in dairy products. International Journal of Food Microbiology, 140: 76-83.

Martınez-Blanch J F, Sanchez G, Garay E and Aznar R. (2009). Development of a real-time PCR assay for detection and quantification of Enterotoxigenic members of Bacillus cereus group in food samples International Journal of Food Microbiology, 135: 15-21.

Messelha“usser U, Ka“mpf P, Colditz J, Bauer H, Schreiner H, Holler C, Busch U. (2011). Qualitative and quantitative detection of human pathogenic Yersinia enterocolitica in different food matrices at retail level in Bavaria. Foodborne Pathogen dis, 8(1): 39-44

Nanu E, Latha C, Sunil B et al. (2007). Quality Assurance and public health safety of raw milk at the production point. Am J Food Tech, 2: 145-52.

Nguyen Yen Thi Hoang, Zhenzhen Wang, Haruhiko Maruyama, Yoichiro Horii, Nariaki Nonaka, Ayako Yoshida. (2016). Evaluation of real-time PCR assay for the detection of Ascaris Suum contamination in meat and organ meats. Journal of food safety, 37(2).

Omiccioli E, Amagliani G, Brandi G, Bruce I J, Magnani M. (2009). Simultaneous direct detection of Salmonella spp., Listeria monocytogenes and Escherichia coli O157 in milk samples by magnetic extraction and multiplex PCR. J Rapid Methods Autom Microbiol, 17: 195-213. 
Priha O, Hallamaa K, Saarela M, Raaska L. (2004). Detection of Bacillus cereus group bacteria from cardboard and paper with real-time PCR. Journal of Industrial Microbiology \& Biotechnology , 31: 161-169.

Theresa A, Nicklas D R, PH LN. (2003). Calcium intake trends and Health Consequences from childhood through Adulthood. J Am Coll Nutr , 22: 340-56.

Ludwig W, Schleifer K H. (2003). How quantitative is quantitative PCR with respect to cell counts Syst. Appl. Microbiol, 23: 556-562.

Stephan J. Ott, Meike Musfeldt, Uwe Ullmann, Jochen Hampe, and Stefan Schreiber. (2004). Quantification of Intestinal Bacterial Populations by Real-Time PCR with a Universal Primer Set and Minor Groove Binder Probes: a Global Approach to the Enteric Flora. Journal of clinical microbiology, 2566-2572.

Table 1. Forward and reverse primers

\begin{tabular}{|c|c|c|c|}
\hline primers & Sequence & $\mathrm{T}_{\mathrm{m}}$ & $\mathrm{Mw}$ \\
\hline Forward & 5' $^{\prime}$ - TCATCGCACCGTCAAAGGAACC - 3' & 62.7 & 6673.3 \\
\hline Reverse & 5'- GTGAAATTATCGCCACGTTCGGGCAA - 3' $^{\prime}$ & 68.5 & 7995.1 \\
\hline Probe & $\begin{array}{r}\text { (6- FAM) - 5' - CGTATTACCGCGGCTGCTGGCAC - } \\
\text { 3' - (TAMRA) }\end{array}$ & 59.9 & 6081.4 \\
\hline
\end{tabular}


Table 2. Results of assessing microbial load by qPCR and bacterial culture methods

\begin{tabular}{|c|c|c|c|}
\hline Samples No. & $\begin{array}{l}\text { Culture } \\
\text { (cfu/ml) }\end{array}$ & $\begin{array}{l}\text { Given Conc } \\
\text { (copies/ml) }\end{array}$ & qPCR (copies/ml) \\
\hline PM 1 & .00 & & 64 \\
\hline PM 2 & 1130 & & 2940 \\
\hline PM 3 & 0 & & 55 \\
\hline PM 4 & 0 & & 254 \\
\hline PM 5 & 6300 & & 3090 \\
\hline PM 6 & 1600 & & 5628 \\
\hline PM 7 & 4000 & & 5550 \\
\hline PM 8 & 100 & & 4181 \\
\hline PM 9 & .00 & & 133 \\
\hline PM 10 & 10000 & & 7000 \\
\hline PM 11 & 6000 & & 6598 \\
\hline PM 12 & 2000 & & 5289 \\
\hline PM 13 & 10000 & & 4541 \\
\hline PM14 & 400 & & 4130 \\
\hline PM15 & 0 & & 121 \\
\hline PM16 & 2000 & & 4619 \\
\hline PM 17 & 1300 & & 2885 \\
\hline PM 18 & 0 & & 695 \\
\hline PM 19 & 0 & & 500 \\
\hline PM 20 & 500 & & 3221 \\
\hline PM 21 & 2000 & & 3804 \\
\hline PM 22 & 0 & & 101 \\
\hline PM 23 & 7000 & & 7071 \\
\hline PM 24 & 1000 & & 5445 \\
\hline PM 25 & 2100 & & 2207 \\
\hline PM 26 & 2000 & & 2210 \\
\hline PM 27 & 1000 & & 2248 \\
\hline PM 28 & 6500 & & 7000 \\
\hline PM 29 & 4000 & & 5445 \\
\hline PM 30 & 1500 & & 2200 \\
\hline Standard & & 50 & 52 \\
\hline Standard & & 600 & 554 \\
\hline Standard & & 5000 & 5222 \\
\hline
\end{tabular}

This article is protected by copyright. All rights reserved. 


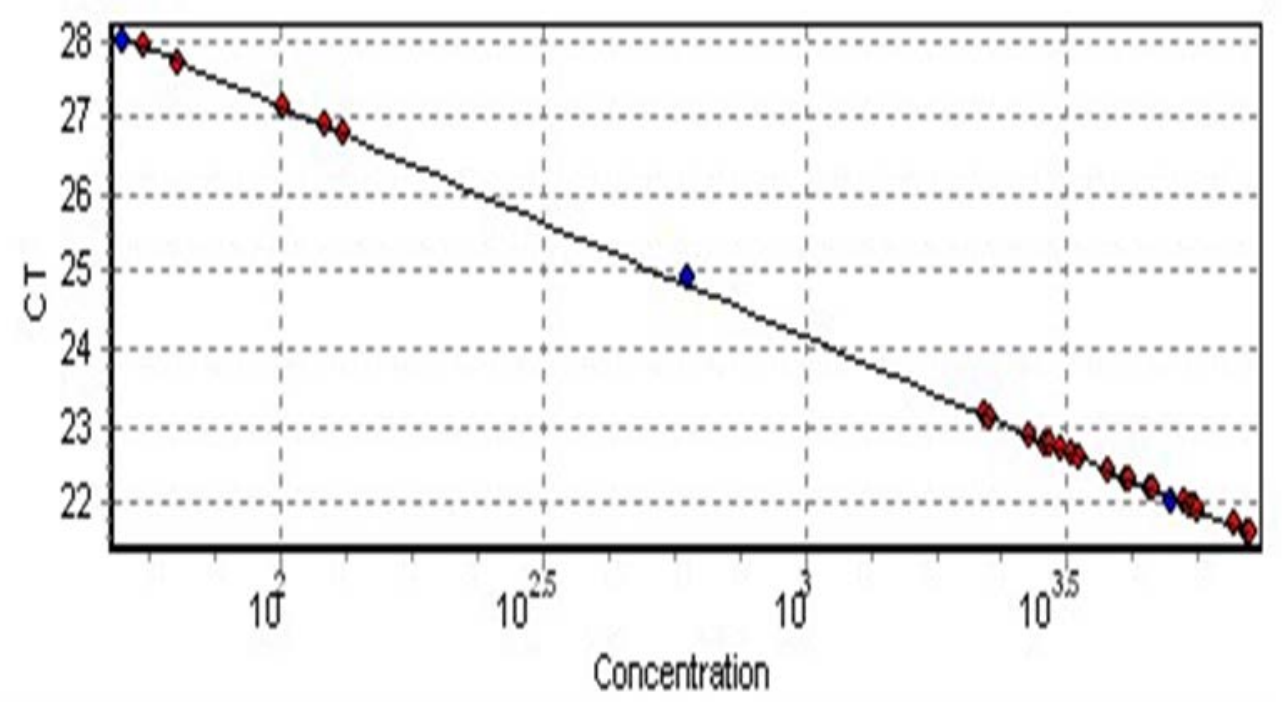

Figure1. Standard Curve

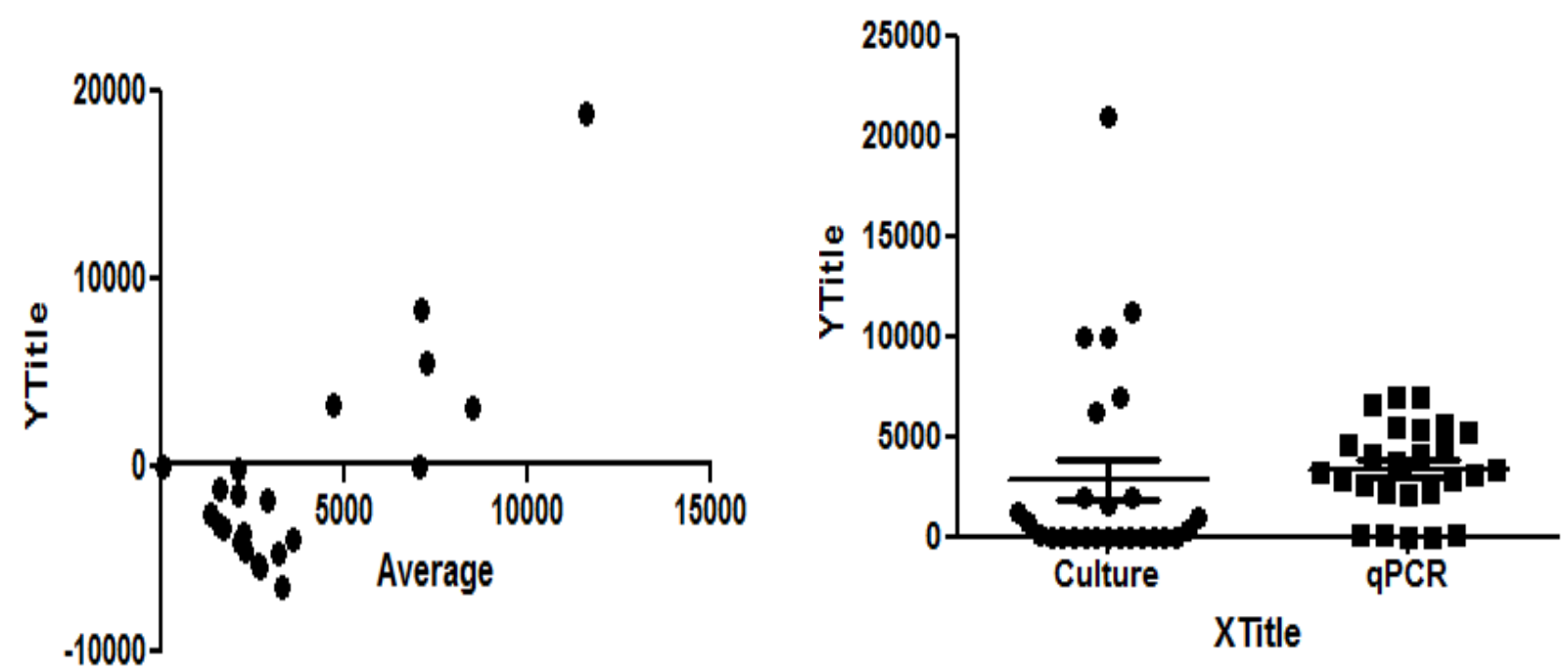

Figure2. Bland-Altman plot; (a) difference of data; (b) difference vs average 


\section{University Library}

\section{- M M N E R VA A gateway to Melbourne's research publications}

Minerva Access is the Institutional Repository of The University of Melbourne

Author/s:

Farhoudi, A;Ghajarbeygi, P;Jozani, RAJ;Mahmoudi, R;Mardani, K

Title:

Comparison of real-time PCR and cultural method for detection of bacterial load in pasteurized milk

Date:

2019-06-01

Citation:

Farhoudi, A., Ghajarbeygi, P., Jozani, R. A. J., Mahmoudi, R. \& Mardani, K. (2019). Comparison of real-time PCR and cultural method for detection of bacterial load in pasteurized milk. JOURNAL OF FOOD SAFETY, 39 (3), https://doi.org/10.1111/jfs.12624.

Persistent Link:

http://hdl.handle.net/11343/285262 